\title{
KEMAMPUAN BERPIKIR KRITIS PESERTA DIDIK PADA PEMBELAJARAN DENGAN MODEL CONCEPT ATTAINMENT DAN MODEL INDUCTIVE THINKING MATERI PENCEMARAN LINGKUNGAN
}

\section{Students' Critical Thinking Skills in Concept Attainment and Inductive Thinking Learning Model Environment Pollution Concept}

\author{
Asep Yudi Supriatan ${ }^{1)}$, Endang Surahman ${ }^{1)}$, Suharsono ${ }^{1)}$ \\ ${ }^{1)} J u r u s a n$ Pendidikan Biologi, Fakultas Keguruan dan Ilmu Pendidikan Universitas Siliwangi ${ }^{1}$, \\ Jl. Siliwangi No. 24 Kotak Pos 164 Tlp. (0265) 330634 Tasikmalaya 46115 \\ Email korespondensi: ayudi7@gmail.com
}

\section{Info Artikel}

Sejarah Artikel:

Diterima: 22 Mei 2019

Disetujui: 27 Mei 2019

Dipublikasikan: 30 Juni 2019

\section{Keywords:}

Kemampuan berpikir kritis, Model Concept Attainment, Model Inductive Thinking, Materi Pencemaran Lingkungan

\begin{abstract}
Abstrak
Tujuan dari artikel ini adalah untuk memberikan informasi mengenai perbedaan kemampuan berpikir kritis peserta didik yang proses pembelajarannya menggunakan model pembelajaran Concept Attainment dan model pembelajaran Inductive Thinking pada materi pencemaran lingkungan di kelas X MIA MAN Awipari Kota Tasikmalaya. Penelitian ini dilaksanakan pada bulan November 2015 sampai dengan bulan April 2016 di MAN Awipari Kota Tasikmalaya. Metode yang digunakan pada penelitian ini adalah pre eksperimental. Populasi dalam penelitian ini adalah seluruh kelas X MIA MAN Awipari Kota Tasikmalaya sebanyak 4 kelas, dengan jumlah peserta didik sebanyak 128 orang. Sampel penelitian sebanyak 2 kelas yaitu, kelas X MIA 3 dengan proses pembelajaran menggunakan model pembelajaran Concept Attainment dan kelas X MIA 4 dengan proses pembelajaran menggunakan model pembelajaran Inductive Thinking, yang diambil dengan teknik Purposive Sampling. Instrumen yang digunakan dalam penelitian ini adalah tes kemampuan berpikir kritis peserta didik pada materi Pencemaran Lingkungan. Tes ini berupa soal uraian, sebanyak 11 nomor dari 15 butir soal yang telah valid yang disesuaikan dengan 11 indikator soal dalam berpikir kritis. Teknik analisis data yang digunakan adalah uji perbedaan dua rata-rata (uji-t). Hasil penelitian menunjukkan bahwa ada perbedaan kemampuan berpikir kritis peserta didik yang proses pembelajarannya menggunakan model pembelajaran Concept Attainment dan model pembelajaran Inductive Thinking pada materi pencemaran lingkungan di kelas X MIA MAN Awipari Kota Tasikmalaya.
\end{abstract}

\section{Abstract}

The aim of this article was to provide information about different of students' critical thinking skills which learning process used concept attainment learning model and inductive thinking learning model on environmental pollution concept at grade $X$ MIA MAN Awipari Kota Tasikmalaya. This reserch conducted in November 2015 to April 2016 in MAN Awipari Kota Tasikmalaya. Research method that used in this reaserch was pre-experimental. The population in this research were 4 classes $X$ MIA MAN Awipari Kota Tasikmlaya that consists of 128 students in total. The 2 sample chosen are class X MIA 3 with the learning process used concept attainment learning model and class X MIA 4 with the learning process used the inductive thinking learning model, taken with a purposive sampling technique. Test of critical thinking skills of environmental pollution concept used as instrument to gather data. The tests form was essay consists of 11 numbers and adjusted with 11 critical thinking skill's indicators. Hypotheses analysis was using test of difference between two averages (uji-t). The result shown that there were differences between student's critical thinking skills that the learning process using the concept attainment and inductive thinking learning model on environmental pollution concept at class X MIA MAN Awipari Tasikmalaya.

(C) 2019 Universitas Siliwangi

\footnotetext{
$\triangle$ Alamat korespondensi:

Jurusan Pendidikan Biologi FKIP Universitas Siliwangi

Gedung Perkantoran FKIP Lt. 3

Jalan Siliwangi No. 24 Kota Tasikmalaya 46115

HP. 08112344989 (a.n. Rinaldi Rizal Putra, M.Sc.)

E-mail: bioedusiana@unsil.ac.id
}

ISSN 2684-7604 (Online)

ISSN 2477-5193 (Printed) 


\section{PENDAHULUAN}

Perkembangan ilmu pengetahuan dan teknologi yang semakin pesat menyebabkan arus informasi menjadi cepat dan tanpa batas. Hal ini berdampak langsung pada berbagai bidang kehidupan, termasuk dalam bidang pendidikan. Proses pendidikan pun dituntut untuk menyiapkan serta menghasilkan sumber daya manusia yang berkualitas, yang mampu memproses informasi secara baik dan benar.

Salah satu upaya dalam bidang pendidikan yang dapat dilakukan untuk mencetak sumber daya manusia yang berkualitas yaitu dengan membiasakan membentuk budaya berpikir kompleks pada peserta didik dalam proses pembelajarannya. Salah satu kemampuan berpikir kompleks adalah kemampuan berpikir kritis yang dikembangkan oleh Norris dan Ennis, 1989 (Alec Fhiser 2009:4). Sejalan dengan pemikiran Ennis (Costa, 1985) bahwa berpikir kritis adalah kemampuan berpikir reflektif yang berfokus pada pola pengambilan keputusan tentang apa yang harus diyakini dan harus dilakukan.

Peserta didik dituntut untuk dapat menganalisis, mensintesis dan menyimpulkan informasi-informasi yang didapatkan dengan kemampuan berpikir kritisnya, sehingga peserta didik mampu membedakan antara informasi yang baik dan informasi yang buruk, serta dapat mengambil keputusan terhadap informasi yang didapatkannya (Muh. Tanwil dan Liliasari, 2013). Selain itu tujuan melatih kemampuan berpikir kritis kepada peserta didik adalah untuk menyiapkan peserta didik menjadi seorang pemikir kritis, mampu memecahkan masalah, dan menjadi pemikir independen, sehingga mereka dapat menghadapi kehidupan, menghindarkan diri dari indoktrinasi, penipuan, pencucian otak, mengatasi setiap masalah yang dihadapi, dan membuat keputusan dengan tepat dan bertanggung jawab. (Muh. Tanwil dan Liliasari, 2013).

Kemampuan berpikir kritis adalah kemampuan yang dapat diajarkan, sehingga kemampuan ini dapat dipelajari (Muh. Tanwil dan Liliasari, 2013). Salah satu cara mengembangkan kemampuan berpikir kritis yaitu melalui pembelajaran biologi. Pada pembelajaran biologi, peserta didik diajarkan untuk memperoleh pengetahuan melalui pengumpulan data dengan eksperimen, pengamatan, dan komunikasi untuk menghasilkan suatu penjelasan yang dapat dipercaya kebenarannya. Kenyataan di sekolah, pembelajaran biologi belum banyak yang berorientasi ke arah pembiasaan dan peningkatan kecakapan keterampilan berpikir tingkat tinggi (berpikir kritis), tetapi masih menitik beratkan pada kemampuan kognitif tingkat rendah saja.

Berdasarkan hasil observasi yang telah dilakukan di Madrasah Aliyah Negeri Awipari Kota Tasikmalaya melalui wawancara dengan guru biologi dan pengamatan dalam proses pembelajaran, menunjukkan proses pembelajaran dan soal-soal evaluasi yang diberikan belum berorientasi untuk mengembangkan kemampuan berpikir kritis peserta didik, sehingga peserta didik kurang dilatih untuk mengembangkan kemampuan berpikir kritis. Hal ini mengakibatkan rendahnya kemampuan berpikir kritis peserta didik. Peserta didik kesulitan menganalisis informasi yang ada, cenderung menerima apa adanya informasi yang disampaikan maupun yang tertulis dalam buku, dan pasif dalam mengajukan pertanyaan maupun menjawab pertanyaan dari permasalahan yang diajukan guru, serta mengemukakan ide ataupun gagasan penyelesaian masalah.

Maka berdasarkan hal tersebut, diperlukan suatu upaya revitalisasi dalam proses pembelajaran dikelas, terutama dalam penggunaan model pembelajaran yang tepat sesuai kondisi peserta didik sehingga peserta didik mampu berpikir kritis dalam menanggapi setiap permasalahan yang disajikan oleh guru dalam proses pembelajaran. Rumpun model pembelajaran pemrosesan informasi adalah salah satu solusi yang ditawarkan untuk melihat perbedaan kemampuan berpikir kritis peserta didik, karena dalam rumpun model pembelajaran ini peserta didik dituntut untuk menggali informasi sebanyak mungkin yang nantinya harus mereka analisis, sintesis dan evaluasi mana konsep yang tepat dan mana konsep yang sumbang, model pembelajaran 
yang termasuk kedalam rumpun model ini adalah model pembelajar Concept Attainment dan model pembelajaran Inductive Thinking.

Model pembelajaran Concept Attainment adalah salah satu model pembelajaran dari rumpun model pemrosesan informasi yang dikembangkan oleh seorang teoretikus Jerome Bruner (1967) (Bruce Joyce dan Weil M, 2009), model ini merupakan proses mencari dan mendaftar sifat-sifat yang dapat digunakan untuk membedakan contoh-contoh yang positif dengan contoh-contoh yang negatif dari berbagai kategori , sedangkan model pembelajaran Inductive Thinking adalah salah satu model pembelajaran dari rumpun model pemrosesan informasi, yang dikembangkan oleh seorang teoretikus Hilda Taba (1971), (Bruce Joyce dan Weil M, 2009), model pembelajaran ini mendasari asumsi bahwa peserta didik adalah konseptor alamiah.

Masalah penelitian ini dirumuskan sebagai berikut: "adakah perbedaan kemampuan berpikir kritis peserta didik yang proses pembelajarannya menggunakan model pembelajaran Concept Attainment dan model pembelajaran Inductive Thinking pada materi Pencemaran Lingkungan di kelas X MIA Madrasah Aliyah Negeri Awipari Kota Tasikmalaya?".

Tujuan dari penelitian ini adalah untuk mengetahui profil kemampuan berpikir kritis peserta didik yang proses pembelajarannya menggunakan model pembelajaran Concept Attainment dan model pembelajaran Inductive Thinking pada materi Pencemaran Lingkungan di kelas X MIA Madrasah Aliyah Negeri Awipari Kota Tasikmalaya.

\section{METODE}

Metode Penelitian yang digunakan dalam penelitian ini metode pre eksperimental (quasi eksperimen), karena pada penelitian ini peneliti tidak melakukan pengkondisian semua keadaan sesuai dengan eksperimen murni, dengan model pembelajaran Concept Attainment dan model pembelajaran Inductive Thinking sebagai variabel bebas serta kemampuan berpikir kriti peserta didik sebagai variabel terikat.
1. Populasi dan Sampel

Populasi dalam penelitian ini adalah seluruh kelas X MIA Madrasah Aliyah Negeri Awipari Kota Tasikmalaya tahun ajaran 2015/2016 sebanyak 4 kelas dengan sampel yang digunakan adalah 2 kelas, yang diambil dengan menggunakan teknik Purposive Sampling, yaitu kelas X MIA 3 dengan menggunakan model pembelajaran Concept Attainment dan kelas X MIA 4 menggunakan model pembelajaran Inductive Thinking, atas dasar kebutuhan peneliti dengan alasan X MIA 3 dan X MIA 4 memiliki kemampuan yang hampir sama, belajar dengan guru yang sama, dan memiliki rata-rata nilai raport lebih tinggi dibanding kedua kelas yang lain.

2. Desain Penelitian

Desain yang digunakan dalam penelitian ini adalah one shot case study, artinya penulis mengadakan perlakuan satu kali yang diperkirakan sudah mempunyai pengaruh, kemudian dilakukan tes. Desain penelitian yang digunakan menurut Suharsimi Arikunto adalah:

\begin{tabular}{|c|c|}
\hline Rancangan & $\begin{array}{ll}: & \mathrm{O} \\
: & \mathrm{O}\end{array}$ \\
\hline \multicolumn{2}{|l|}{ Keterangan } \\
\hline $\mathrm{X}_{1}$ & $\begin{array}{lr}\text { Perlakuan } & \text { (treatment) } \\
\text { pertama } & \text { dengan } \\
\text { menggunakan } & \text { model } \\
\text { pembelajaran } & \text { Concept } \\
\text { Attainment } & \end{array}$ \\
\hline $\mathrm{X}_{2}$ & $\begin{array}{l}\text { Perlakuan (treatment) ke } \\
\text { dua dengan menggunakan } \\
\text { model pembelajaran } \\
\text { Inductive Thinking. }\end{array}$ \\
\hline $\mathrm{O}$ & $\begin{array}{l}\text { Hasil observasi setelah } \\
\text { diberikan perlakuan. }\end{array}$ \\
\hline
\end{tabular}

(Suharsimi Arikunto (2013:124)

3. Langkah-Langkah Penelitian

Langkah-langkah penelitian yang ditempuh dalam penelitian ini yaitu : tahap persiapan yang meliputi observasi, pengajuan judul, penyusunan proposal, dan instrumen penelitian, seminar penelitian, uji coba instrumen penelitian; tahap pelaksanaan meliputi pelaksanaan 
pembelajaran dengan menggunakan model pembelajaran Concept Attainment dan model pembelajaran Inductive Thinking, post test, dan tahap pengolahan data seperti analisis data terhadap hasil test kemampuan berpikir kritis yang diperoleh dari hasil penelitian dan membuat kesimpulan.

4. Teknik Pengumpulan Data

Teknik pengumpulan data yang digunakan dalam penelitian ini adalah teknik tes. Tes yang digunakan pada penelitian ini adalah tes tertulis dalam bentuk tes objektif essay untuk membandingkan kemampuan berpikir kritis peserta didik akibat perlakuan yang berbeda.

5. Instrumen Penelitian

Instrumen yang digunakan dalam penelitian ini adalah tes kemampuan berpikir kritis peserta didik pada materi pencemaran lingkungan dengan bentuk uraian serta aspek yang diukur hanya dominan kognitif untuk berpikir tingkat tinggi (berpikir kritis) yang dibatasi atas tingkatan menganalisis (C4) dan mengevaluasi (C5), yang dikaitkan pada indikator berpikir kritis hasil pengembangan Ennis (Ennis, R. H. 2001) . Uji validitas tiap butir soal dilakukan dengan menggunakan program Anates versi 4.0 for windows dengan program Anates untuk soal uraian. Berdasarkan hasil analisis butir soal dengan menggunakan program Anates diperoleh 15 butir soal yang memenuhi kriteria valid dan 5 butir soal yang tidak memenuhi kriteria valid, maka diperoleh reliabilitas uji instrumen sebesar 0,88 yang berarti bahwa tes yang diberikan mempunyai tingkat reliabilitas sangat tinggi. Untuk memenuhi kebutuhan penelitian, penulis hanya mengambil 11 soal dari 15 soal yang telah valid dan reliabel, dengan disesuaikan pada 11 indikator soal berpikir kritis.

6. Teknik Pengolahan dan Analisis Data

Teknik pengolahan dan analisis data dalam penelitian ini yaitu dengan uji persyaratan analisis menggunakan Uji Normalitas dengan Uji Chi Kuadrat dan Uji homogenitas dengan uji $F_{\text {maksimum, }}$ kemudian dilanjutkan dengan uji hipotesis menggunakan uji t, (Edi Hernawan 2014).

7. Tempat dan Waktu

Penelitian dilaksanakan di MAN

Awipari Kota Tasikmalaya telah dilaksanakan pada bulan November 2015 sampai dengan bulan April 2016.

\section{HASIL DAN PEMBAHASAN}

Data yang diperoleh dari penelitian ini meliputi data posttest dari kemampunan berpikir kritis peserta didik pada materi pencemaran lingkungan di kelas X MIA MAN Awipari Kota Tasikmalaya seperti yang ditampilkan pada Tabel 1 berikut.

Tabel 1. Hasil Tes Kemampuan Berpikir Kritis Peserta Didik Kelas XI MIA 3 Dan XI MIA 4

\begin{tabular}{ccc}
\hline \multirow{2}{*}{ Statistik } & \multicolumn{2}{c}{ Nilai Posttest } \\
\cline { 2 - 3 } & XI MIA 3 & XI MIA 4 \\
\hline Maksimum & 32 & 32 \\
Minimum & 22 & 21 \\
Rata-rata & 25,79 & 27,32 \\
Varians & 7,97 & 9,06 \\
Standar deviasi & 2,82 & 3,01 \\
KKM & 24,75 & 24,75 \\
\hline
\end{tabular}

Kemudian, untuk mengetahui apakah data yang diperoleh berdistribusi normal atau tidak, maka dilakukan uji normalitas data dengan hasil seperti yang terdapat pada Tabel 2 berikut.

Tabel 2. Ringkasan Hasil Uji Normalitas

\begin{tabular}{ccccc}
\hline Data & $\chi_{\text {hitung }}^{\mathbf{2}}$ & $\chi_{\text {tabel }}^{\mathbf{2}}$ & Hasil Analisis & Kesimpulan \\
\hline $\mathrm{A}$ & 4,6062 & 7,815 & $\chi_{\text {hitung }}^{2}<\chi_{\text {tabel }}^{2}$ & Terima $\mathrm{H}_{\mathrm{o}}$ \\
$\mathrm{B}$ & 2,701 & 7,815 & $\chi_{\text {hitung }}^{2}<\chi_{\text {tabel }}^{2}$ & Terima $\mathrm{H}_{\mathrm{o}}$ \\
\hline
\end{tabular}


Berdasarkan hasil analisis dengan menggunakan uji normalitas dapat disimpulkan bahwa data skor kemampuan berpikir kritis peserta didik yang proses pembelajarannya menggunakan model pembelajaran Concept Attainment dan model pembelajaran Inductive Thinking berasal dari populasi yang berdistribusi normal.

Berikutnya, untuk mengetahui apakah kedua varians data bersifat homogen, maka dilakukan pengujian dengan uji $F_{\text {maksimum }}$ dengan hasil yang ditampilkan pada Tabel 3 berikut.

Tabel 3. Ringkasan Hasil Uji Homogenitas dengan menggunakan $\mathrm{F}_{\text {maksimum }}$

\begin{tabular}{cccc}
\hline $\mathbf{F}_{\text {hitung }}$ & $\mathbf{F}_{\text {tabel }}$ & $\begin{array}{c}\text { Hasil } \\
\text { analisis }\end{array}$ & Kesimpulan \\
\hline 1,14 & 1,791 & $\begin{array}{c}\mathrm{F}_{\text {hitung }}< \\
\mathrm{F}_{\text {tabel }}\end{array}$ & Terima $\mathrm{H}_{0}$ \\
\hline
\end{tabular}

Berdasarkan hasil analisis dari uji homogenitas tersebut diperoleh nilai $\mathrm{F}_{\text {hitung }}=$ 1,14 dan $\mathrm{F}_{\text {tabel }}=1,791$ Jadi menurut hasil analisis tersebut didapat $F_{\text {hitung }}<F_{\text {tabel }}$, sehingga dapat disimpulkan bahwa kedua varians data tersebut bersifat homogen.

Kemudian, untuk mengetahui apakah perlakukan yang diberikan memberikan hasil yang berbeda, maka dilakukan uji hipotesis dengan menggunakan Uji t dengan hasil seperti yang ditampilkan pada Tabel 4 berikut.

Tabel 4. Ringkasan Hasil Uji t

\begin{tabular}{cccc}
\hline $\mathbf{t}_{\text {hitung }}$ & $\mathbf{t}_{\text {tabel }}$ & $\begin{array}{c}\text { Hasil } \\
\text { analisis }\end{array}$ & Kesimpulan \\
\hline$-6,65$ & 1,998 & thitung berada Tolak $\mathrm{H}_{0}$ \\
& atau - & didaerah & \\
1,998 & penolakan & \\
& & $\mathrm{H}_{0}$ & \\
\end{tabular}

Dengan demikian, hipotesis yang diajukan "Ada perbedaan kemampuan berpikir kritis peserta didik yang proses pembelajarannya menggunakan model pembelajaran Concept Attainment dan model pembelajaran Inductive Thinking pada materi pencemaran lingkungan di kelas X MIA MAN Awipari Kota Tasikmalaya" dapat diterima.
Berdasarkan uji hipotesis dari hasil penelitian yang telah dilakukan di kelas $\mathrm{X}$ MIA MAN Awipari Kota Tasikmalaya yang dijadikan sampel menunjukkan nilai $t_{\text {hitung }}$ sebesar -6,65 dan nilai $t_{\text {tabel }}$ sebesar-1,998 atau 1,998 yang artinya nilai $t_{\text {hitung }}$ berada didaerah penolakan $\mathrm{H}_{0}$, maka hasil dari uji hipotesi menyatakan ada perbedaan kemampuan berpikir kritis peserta didik yang proses pembelajarannya menggunakan model pembelajaran Concept Attainment dan model pembelajaran Inductive Thinking pada materi pencemaran lingkungan di kelas X MIA MAN Awipari Kota Tasikmalaya.

Adanya perbedaan tersebut dapat dipengaruhi oleh perbedaan proses pembelajaran di antaranya, proses dan keadaan pembelajaran di kelas $\mathrm{X}$ MIA 4 yang menggunakan model pembelajaran Inductive Thinking, peserta didik dalam proses pembelajaran dengan menggunakan model pembelajaran Inductive Thinking diberi keleluasaan dan dituntut untuk mengakses serta menggali sebanyak mungkin informasi tentang materi yang disajikan guru dari berbagai sumber dan literatur, setelahnya guru menyajikan fenomena terkait berbagai isu pencemaran lingkungan dalam berupa gambar.

Peserta didik menjadi terpacu aktif dan dituntun untuk mendaftar serta mengelompokan segala informasi yang berkaitan dengan materi pencemaran lingkungan. Peserta didik pun dituntut untuk berbicara dan menyampaikan informasi yang telah diperolehnya untuk disampaikan kepada peserta didik lain untuk ditanggapi dan atau disanggah, dan atau di tambahkan sehingga informasi yang muncul kepermukaan dalam proses pembelajaran dikelas semakin komplek, luas namun tetap mengerucut pada satu konsep pencemaran lingkungan.

Dengan penggunaan model pembelajaran Inductive Thinking tersebut peserta didik belajar mengasah pikirannya untuk mengaitkan hubungan-hubungan konsep yang berangkat dari indra penglihatannya yang bersifat khusus menjadi konsep yang dapat dijelaskan secara umum.

Sedangkan situasi pembelajaran di kelas $\mathrm{X}$ MIA 3 yang proses pembelajarannya 
menggunakan model pembelajaran Concept Attainment, peserta didik merasa kebingungan dan harus slalu diberikan stimulus sehingga peserta didik memahami konsep dalam materi, ini membuat proses pembelajaran dikelas tidak berkembang, rasa malu dan takut salah dalam menyampaikan pendapat serta gagasan pun sanggat memberikan pengaruh ketika proses pembelajaran dikelas berlangsung, sehingga proses pembelajaran dikelas lebih vakum dan guru harus lebih aktif membangkitkan motivasi peserta didik untuk berani memberikan gagasannya terkait konsep dan materi yang sedang dipelajari.

Dengan demikian, kemampuan berpikir kritis peserta didik yang proses pembelajarannya menggunakan model pembelajaran Inductive Thinking lebih menunjukan hasil yang baik dalam mengasah kemampuan berpikir kritis peserta didik dibandingkan dengan kemampuan berpikir kritis peserta didik yang proses pembelajarannya menggunakan model pembelajaran Concept Attainment. Hal tersebut ditunjukan dengan hasil tes kemampuan berpikir kritis peserta didik pada materi pencemaran lingkungan Gambar 1, yang menunjukan rata-rata hasil tes peserta didik yang proses pembelajarannya menggunakan model pembelajaran Inductive Thinking memiliki hasil rata-rata lebih besar yaitu 27,32 dibandingkan dengan peserta didik yang proses pembelajarannya menggunakan model pembelajaran Concept Attainment dengan ratarata hasil tes sebesar 25,79.

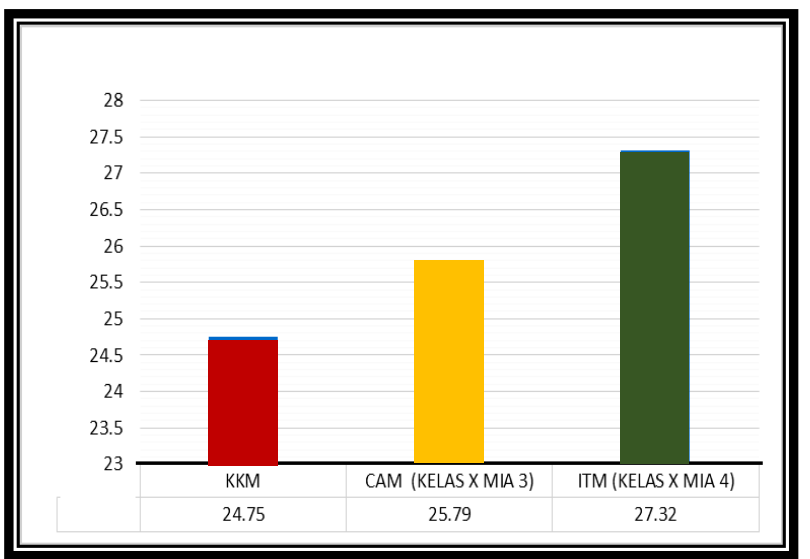

Gambar 1. Diagram Batang Perbedaan Skor Rata-rata Hasil Tes Kemampuan Berpikir Kritis Peserta Didik

\section{SIMPULAN, SARAN, DAN REKOMENDASI}

Berdasarkan hasil penelitian, diperoleh simpulan bahwa ada perbedaan dalam kemampuan berpikir kritis peserta didik yang proses pembelajaranya menggunakan model pembelajaran Concept Attainment dan model pembelajaran Inductive Thinking pada materi pencemaran lingkungan di kelas X MIA MAN Awipari Kota Tasikmalaya. Proses pembelajaran yang menggunakan model pembelajaran Inductive Thinking mampu menunjukan kemampuan berpikir kritis peserta didik yang lebih baik serta unggul dibandingkan proses pembelajaran dengan menggunakan model pembelajaran Concept Attainment yang diterapkan pada materi pencemaran lingkungan di kelas X MIA MAN Kota Tasikmalaya.

Penulis mengajukan dan mengusulkan beberapa saran sebagai berikut: dalam penerapan model pembelajaran Concept Attainment guru hendaknya mengetahui terlebih dahulu sejauh mana pemahaman anak pada materi tersebut sebelum diterapkan dalam proses pembelajaran, guru hendaknya lebih aktif memberikan stimulus serta motivasi agar peserta didik lebih terpacu untuk aktif mengajukan pendapat guna memahami konsep yang mereka harus analisis dan pecahkan, guru hendaknya banyak melatih peserta didik untuk terbiasa membangun konsep dalam memecahkan permasalahan dalam materi pembelajaran, dan bagi peneliti selanjutnya, 
hendaknya mencoba menerapkan model pembelajaran Concept Attainment dan model pembelajaran Inductive Thinking pada materi yang lain dan atau pada peningkatan kemampuan berpikir tingkat tinggi yang lain, seperti kemampuan berpikir kreatif, atau mempadukan kedua model pada keterampilan proses sain untuk dilihat pengaruhnya.

\section{DAFTAR PUSTAKA}

Arikunto, Suharsimi. (2013). Prosedur Penelitian. Yogyakarta: Rhineka Cipta.

Costa, L.A 1985, Developing Mind-A Resource Book for Teaching Thinking, Association for Supervision and Curriculum Development, Virginia.
Ennis, R. H. (1993). Critical Thinking Assesment. Theory into Practice, Vol. 32(3): pp. $179-186$.

Fisher, A. (2009). Berpikir Kritis Sebuah Pengantar. (terjemahan). Jakarta: Erlangga.

Hernawan, E. (2014). Pengantar Statistika Parametrik Untuk Penelitian Pendidikan. Tasikmalaya: LPPM Universitas Siliwangi.

Joyce, B., and Weil, M (2009). Models of Teaching, Model - model Pengajaran. Yogyakarta: Pustaka Pelajar.

Tanwil, M., dan Liliasari. (2013). Berpikir Kompleks dan Implementasinya dalam Pembelajaran IPA. Makasar : UNM Press. 